CFaculty of Veterinary Medicine, Zagazig University, 44511, Egypt

DOI: $10.21608 / \mathrm{zvjz.2017.28666.}$

\title{
Comparative ameliorative effect of Hydrated sodium calcium aluminosilicate and Saccharomyces cerevisiae (Brewer's yeast) against toxic impact of aflatoxin $B_{1}$ in Oreochromis niloticus (Nile tilapia)
}

\author{
Abd El-Alim F. Abd El-Alim ${ }^{1}$, Azza A. A. Galal ${ }^{1 *}$, Shahira H. Mahmoud ${ }^{2}$ and Walaa A. El- \\ Sayed $^{2}$ \\ ${ }^{1}$ Pharmacology Department, Faculty of Veterinary Medicine, Zagazig University, 44511, Egypt \\ ${ }^{2}$ Animal Health Research Institute, Zagazig Branch, Zagazig 44516, Sharkia, Egypt
}

\begin{abstract}
Different ways have been used in an attempt to decrease the risk of aflatoxicosis in fish. This study was undertaken to compare the possible alleviative effects of hydrated sodium calcium aluminosilicate (HSCAS) and Saccharomyces cerevisiae against the toxic impact of aflatoxin $\mathrm{B}_{1}$ $\left(\mathrm{AFB}_{1}\right)$ on Oreochromis niloticus $(O$. niloticus). Therefore, 180 normal cultured monosex $O$. niloticus were randomly allocated into 6 equal groups. Group 1, was received the basal ration only. Group 2, was fed a basal ration supplemented with $0.5 \%$ HASCAS. Group 3, was fed a basal diet enriched with $0.25 \%$ Saccharomyces cerevisiae. Group 4, was received a diet intoxicated with $2.5 \mathrm{ppm}$ aflatoxin $\mathrm{B}_{1}$. Group 5 , was fed a diet intoxicated with $2.5 \mathrm{ppm} \mathrm{AFB}_{1}$ with $0.5 \%$ HSCAS. Group 6, was fed a diet intoxicated with $2.5 \mathrm{ppm} \mathrm{AFB}_{1}$ with $0.25 \% \mathrm{~S}$. cerevisae. $\mathrm{AFB}_{1}$ intoxication induced mortality $16.67 \%$, leucopenia, lymphopenia, neutrophilia with a significant decrease in phagocytic $\%$ and index. Furthermore, significant increases in serum creatinine, ALT and ALP as well as a significant decrease in total protein, albumin and globulin were recorded. Moreover, accumulation of aflatoxin residues in O. niloticus flesh (5 $\mathrm{ppb})$ and liver $(15 \mathrm{ppb})$. While, supplementation of $\mathrm{AFB}_{1}$ intoxicated diet either with $S$. cerevisiae or HSCAS ameliorated the drastic effects of aflatoxin on $O$. niloticus and $S$. cerevisiae appear to be more effective in the protection of fish from aflatoxicosis than HSCAS.
\end{abstract}

Keywords: Aflatoxin $\mathrm{B}_{1}$, Residues, Hematology, Phagocytosis, HSCAS, Saccharomyces cerevisiae

\section{Introduction}

Mycotoxins are unavoidable contaminants in foods and feed stuffs and are a major problem throughout the world [1]. Aflatoxins (AFs) are a group of structurally related mycotoxins produced as food-borne metabolites by toxigenic strains of Aspergillus parasiticus, Aspergillus flavus and to lesser extent Aspergillus nominus [2]. Aflatoxins have a serious impact on the cultured fish, inducing disease with elevated death-rate and a steady decrease fish quality, in this manner revealing a critical issue in aquacultures [3]. Aflatoxin $\mathrm{B}_{1}$ is the most common and toxic aflatoxins for human, land animals and aquatic organisms, due to its strong carcinogenic, immunosuppressive and mutagenic effects [4].

In spite of good screening programs, election of high quality feed ingredients and raw materials and good storage it is extremely hard to ensure the nonappearance of mycotoxins in aquaculture feeds.

Subsequently, it is insistent to find appropriate ways to face the problem via an effective handling of the hazards caused by mycotoxins contamination [5]. Hydrated sodium calcium aluminosilicate (HSCAS) clay considered an easy, inexpensive and effectual way of aflatoxicosis as it firmly and specifically captures aflatoxins in GIT, lowering their bioavailability and accompanied problems $[6,7]$.

Brewer's yeast (Saccharomyces cerevisiae) was found to have an important antagonistic role toward aflatoxicosis and has immunostimulant in chickens and quails [8,9]. The yeast preparations appear to be effective on a broad range of mycotoxins [10], due to the ability of glucomannans from $S$. cerevisiae to adsorb mycotoxins [11]. S. cerevisiae able to degrade aflatoxin and other mycotoxins as T-2 toxin and zearalenone $[12,10]$. Therefore, the present experiment was carried out to compare the preventive impacts of HSCAS and

*Corresponding author email: (azzapharma@gmail.com), Pharmacology Department, Faculty of $\quad 210$ Veterinary Medicine, Zagazig University, 44511, Egypt. 
Saccharomyces cerevisiae against the drastic effects of $\mathrm{AFB}_{1}$ on Oreochromis niloticus.

\section{Material and Methods}

Aflatoxin $\mathrm{B}_{1} \quad\left(\mathrm{C}_{17} \mathrm{H}_{12} \mathrm{O}_{6}\right)$, generated by toxigenic Aspergillus flavus utilizing polished raw rice as a growth substrate [13] with minor modifications [14].

HSCAS: Trade name, Condition feed, is commercial product made in India and imported by Pharma chemical international company and is composed of Hydrated sodium calcium aluminosilicate $100 \%$.

Saccharomyces cerevisiae: Trade name, Diamond $\mathrm{v}$ original $\mathrm{xp}$, it contains dried yeast (Saccharomyces cerevisiae) fermented product $100 \%$, made in U.S.A.

\section{Experimental Fish}

One hundred and eighty apparently normal cultured monosex Oreochromis niloticus, with average body weight $(35 \pm 5 \mathrm{~g})$, were obtained from Abbassa Fish hatchery, Sharkia Governorate, Egypt. Fish were transported in polyethylene bags filled with one third dechlorinated water enriched by air $(2 / 3)$ to the laboratory of Pharmacology Department, Faculty of Veterinary Medicine, Zagazig University. Fish were acclimated for 2 weeks and kept in glass aquaria filled with chlorine free tap water under laboratory conditions (natural photoperiod $12 \mathrm{~h}$ and temp $(25.5 \pm 2$ $\left.{ }^{\circ} \mathrm{C}\right)$. Persistent aeration was kept in each aquarium by an electric air pump and temp was maintained by heaters. The water parameters (dissolved oxygen, $\mathrm{pH}$ and electric conductivity of the tap water) used in this study were measured using Hack Method (Sigma Laboratory) following WHO, (2001).

\section{Diets used for experimental fish}

The experimental fish were fed on basal diet (contained $30.38 \%$ crude protein and 3000 $\mathrm{kcal} / \mathrm{kg}$ metabolizable energy which composed of fish meal, poultry by product, soybean, vegetable oils, wheat flour, yellow corn, minerals and vitamins mixture. The basal ration was formulated from commercial constituents and was compressed $(1 \mathrm{~mm}$ size pellets) at Fish Research Unit, Faculty of Veterinary Medicine, Zagazig University. Fish were fed twice daily ( 8 am and $2 \mathrm{pm}$ ) at the rate of $3 \%$ of their biomass.

\section{Experimental protocol}

After adaptation period, the healthy fish were haphazardly assigned into six equal groups (3 replicates/group), each replicate contains 10 fish kept in well prepared and persistently aerated aquarium $(80 \times 40 \times 30 \mathrm{~cm})$ containing dechlorinated tap water, experiment had lasted for 42 days.

Group 1 received a basal ration only. Group 2 (HSCAS group): Fish were received a basal diet supplemented with $0.5 \%$ HSCAS [15]. Group 3 (S. cerevisae group): Fish were received a basal ration enriched with $0.25 \%$ Saccharomyces cerevisiae [15]. Group 4 $\left(\mathrm{AFB}_{1}\right.$ group): Fish were received a diet intoxicated with $2.5 \mathrm{ppm}$ aflatoxin $\mathrm{B}_{1}$ [16]. Group 5 ( $\mathrm{AFB}_{1}+\mathrm{HSCAS}$ group): Fish were fed a diet intoxicated with $2.5 \mathrm{ppm} \mathrm{AFB}_{1}$ and supplemented with $0.5 \%$ HSCAS. Group 6 $\left(\mathrm{AFB}_{1}+S\right.$. cerevisiae group): Fish were fed a diet intoxicated with $2.5 \mathrm{ppm} \mathrm{AFB}_{1}$ and supplemented with $0.25 \% \mathrm{~S}$. cerevisae.

\section{Hematological, immunological and biochemical analysis}

Blood samples were collected on $1^{\text {st }}, 2^{\text {nd }}, 4^{\text {th }}$ and $6^{\text {th }}$ weeks of the experiment from the caudal blood vessels. Three blood samples were collected from each group. The $1^{\text {st }}$ sample was gathered in clean sterilized tubes containing heparin as anticoagulant for estimation of phagocytic activity according to method previously illustrated $[17,18]$. The $2^{\text {nd }}$ blood sample was collected in clean sterilized tubes containing EDTA for hematological examination. The $3^{\text {rd }}$ blood sample was collected in plain centrifuge tubes without anticoagulant then centrifuged at $3000 \mathrm{rpm}$ for 15 minutes for serum separation. Hepato-renal injury biomarkers were assessed in the separated serum. Serum alanine aminotransferase (ALT) was measured [19] and alkaline phosphatase (ALP) [20]. Total protein, albumin and creatinine were detected [21-23] respectively. 


\section{Measurement of $A F B_{1}$ residues}

Muscle and liver samples from five fish of each group on $1^{\text {st }}, 2^{\text {nd }}, 4^{\text {th }}$ and $6^{\text {th }}$ weeks of the experiment, were pooled and thoroughly homogenized in a mortem. $\mathrm{AFB}_{1}$ was extracted, filtrated and quantitatively measured by HPLC [24].

\section{Statistical analysis}

All data were analyzed using the SPSS program using one-way ANOVA. Duncan's Multiple Range Test (DMRT) was used to determine differences among means at significance level of 0.05 .

\section{Results}

\section{Effects on survival rate}

Fish fed $\mathrm{AFB}_{1}$ toxicated diet showed $83.33 \%$ survival rate. Adding of HSCAS or $S$. cerevisiae to $\mathrm{AFB}_{1}$ toxicated diet increased the survival rate to $96.67 \%$.

\section{Effects on some hematological parameters}

Inclusion of $\mathrm{AFB}_{1}$ to the $O$. niloticus ration evoked a significant reduction in the total $\mathrm{RBCs}, \mathrm{Hb}$ concentration and $\mathrm{PCV} \%$ in descending manner at different experimental periods comparing with those fed a basal diet only (Fig 1 A, B \&C). Group 5 and 6 revealed a significant elevation in RBCs count, $\mathrm{Hb}$ and PCV\% compared to fish received $\mathrm{AFB}_{1}$ intoxicated ration only (Group 4). Addition of S. cerevisiae to $\mathrm{AFB}_{1}$ intoxicated diet (Group 6 ) induced a significantly higher RBCs count, $\mathrm{Hb}$ content and PCV\% when compared with fish group treated with aflatoxin $\mathrm{B}_{1}$ and HSCAS.

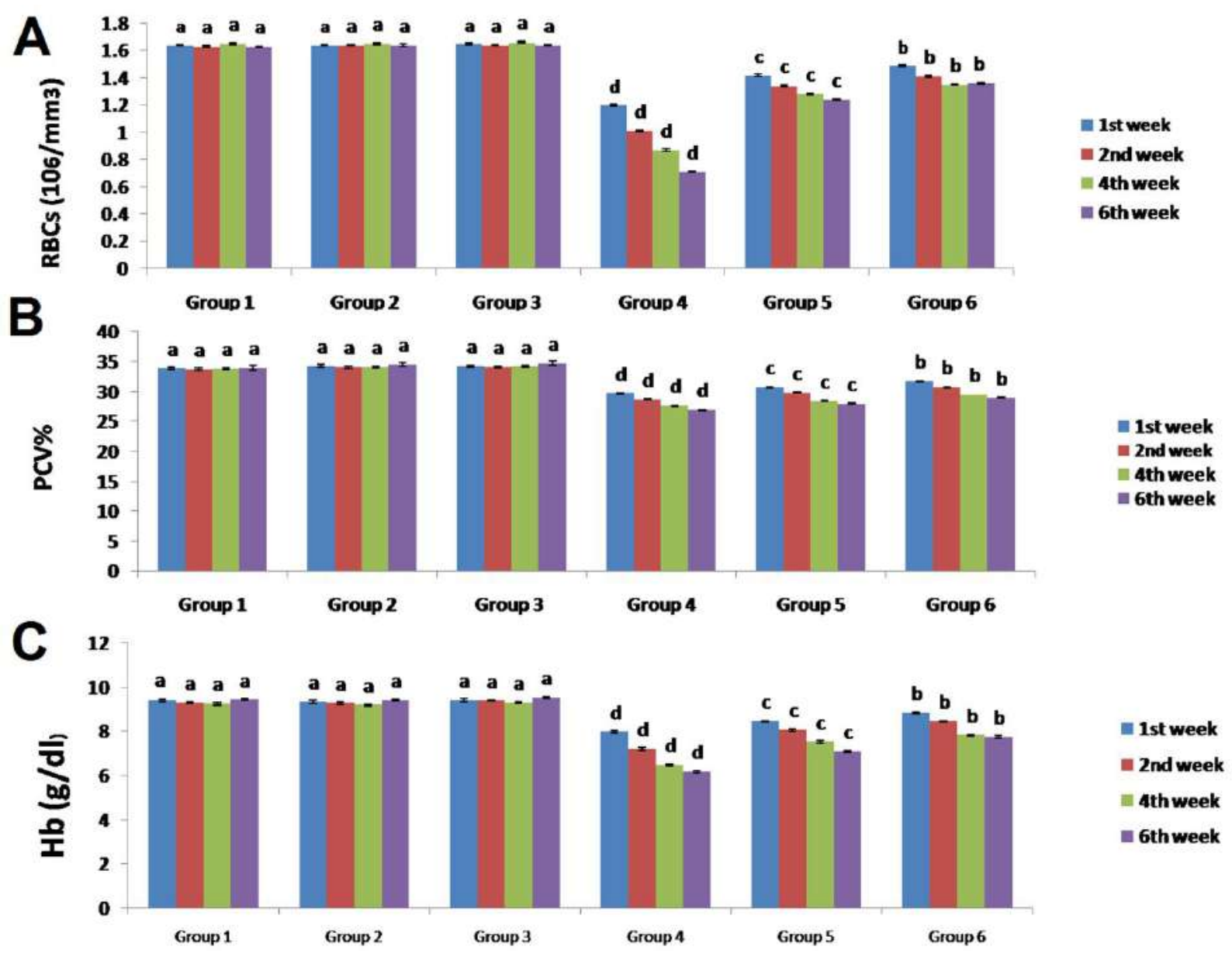

Figure 1: Effect of aflatoxin $B_{1}$ and different antimycotoxins on serum level of RBCs (A), PCV\% (B) and $\mathrm{Hb}$ concentration $(\mathrm{C})$ of $\boldsymbol{O}$. niloticus during different experimental periods 
Fish fed diet enriched with $S$. cerevisiae (Group 3) showed a marked elevation in total leukocytic and lymphocytic counts comparing with the control group, but fish in HSCAS group revealed non-significant change in comparison with the control group (Table 1). The total leukocytes count significantly decreased $(\mathrm{P} \leq 0.05)$ in descending manner at different experimental periods in $\mathrm{AFB}_{1}$ group.
Leucopenia, lymphopenia and neutrophilia are the main picture of the leukogram of $\mathrm{AFB}_{1}$ group. Fish of group 5 and 6 showed a marked increase in WBCs counts compared to fish in group 4 throughout the experimental periods. Addition of $S$. cerevisiae to $\mathrm{AFB}_{1}$ intoxicated diet induced a significant increase in WBCs count and lymphocytic counts when compared with $\mathrm{AFB}_{1}+\mathrm{HSCAS}$ group.

Table 1: Effect of aflatoxin $B_{1}$ and different antimycotoxins on total WBCs, lymphocytes and neutrophils of O. niloticus at different experimental periods

\begin{tabular}{|c|c|c|c|c|c|c|c|}
\hline Groups & Period & G1 & G2 & G3 & G4 & G5 & G6 \\
\hline Parameters & & & & & & & \\
\hline \multirow{8}{*}{ WBCs $\left(10^{3} / \mathrm{mm}^{3}\right)$} & $1^{\text {st }}$ week & 25.70 & 25.69 & 26.51 & 22.46 & 23.71 & 25.02 \\
\hline & & $\pm 0.05^{\mathrm{b}}$ & $\pm 0.02^{\mathrm{b}}$ & $\pm 0.05^{\mathrm{a}}$ & $\pm 0.05^{\mathrm{e}}$ & $\pm 0.04^{\mathrm{d}}$ & $\pm 0.06^{\mathrm{c}}$ \\
\hline & $2^{\text {nd }}$ week & 25.60 & 25.62 & 26.60 & 20.75 & 23.02 & 24.15 \\
\hline & & $\pm 0.04^{\mathrm{b}}$ & $\pm 0.02^{b}$ & $\pm 0.03^{\mathrm{a}}$ & $\pm 0.06^{\mathrm{e}}$ & $\pm 0.05^{\mathrm{d}}$ & $\pm 0.05^{\mathrm{c}}$ \\
\hline & $4^{\text {th }}$ week & 25.58 & 25.56 & 26.70 & 18.74 & 21.76 & 23.19 \\
\hline & & $\pm 0.03^{\mathrm{b}}$ & $\pm 0.03^{\mathrm{b}}$ & $\pm 0.01^{\mathrm{a}}$ & $\pm 0.07^{\mathrm{e}}$ & $\pm 0.07^{\mathrm{d}}$ & $\pm 0.03^{\mathrm{c}}$ \\
\hline & $6^{\text {th }}$ week & 25.67 & 25.70 & 27.25 & 16.64 & 20.48 & 22.99 \\
\hline & & $\pm 0.02^{\mathrm{b}}$ & $\pm 0.02^{\mathrm{b}}$ & $\pm 0.38^{\mathrm{a}}$ & $\pm 0.03^{\mathrm{e}}$ & $\pm 0.03^{\mathrm{d}}$ & $\pm 0.04^{c}$ \\
\hline \multirow{7}{*}{ Neut. \% } & $1^{\text {st }}$ week & 46.00 & 45.40 & 44.00 & 49.60 & 48.40 & 47.20 \\
\hline & & $\pm 0.32^{\mathrm{d}}$ & $\pm 0.24^{\mathrm{d}}$ & $\pm 0.32^{\mathrm{e}}$ & $\pm 0.24^{\mathrm{a}}$ & $\pm 0.51^{\mathrm{b}}$ & $\pm 0.37^{\mathrm{c}}$ \\
\hline & $2^{\text {nd }}$ week & 45.80 & 46.00 & 44.60 & 55.00 & 49.40 & 48.00 \\
\hline & & $\pm 0.37^{\mathrm{d}}$ & $\pm 0.32^{\mathrm{d}}$ & $\pm 0.24^{\mathrm{e}}$ & $\pm 0.32^{\mathrm{a}}$ & $\pm 0.24^{\mathrm{b}}$ & $\pm 0.32^{\mathrm{c}}$ \\
\hline & $4^{\text {th }}$ week & $46.20 \pm$ & $46.60 \pm$ & $44.60 \pm$ & $55.60 \pm$ & 47.40 & 46.40 \\
\hline & & $0.20^{\mathrm{c}}$ & $0.24^{\mathrm{c}}$ & $0.37^{\mathrm{d}}$ & $0.24^{\mathrm{a}}$ & $\pm 0.24^{\mathrm{b}}$ & $\pm 0.24^{\mathrm{c}}$ \\
\hline & $6^{\text {th }}$ week & 45.80 & 46.40 & 44.20 & 56.60 & 46.40 & 45.40 \\
\hline \multirow{9}{*}{ Lymph.\% } & & $\pm .37^{\mathrm{bc}}$ & $\pm 0.24^{\mathrm{b}}$ & $\pm 0.20^{\mathrm{d}}$ & $\pm 0.24^{\mathrm{a}}$ & $\pm 0.24^{\mathrm{b}}$ & $\pm 0.24^{\mathrm{c}}$ \\
\hline & $1^{\text {st }}$ week & 38.00 & 37.60 & 39.80 & 36.00 & 37.60 & 39.00 \\
\hline & & $\pm 0.32^{\mathrm{b}}$ & $\pm 0.24^{\mathrm{b}}$ & $\pm 0.37^{\mathrm{a}}$ & $\pm 0.32^{\mathrm{c}}$ & $\pm 0.24^{\mathrm{b}}$ & $\pm 0.32^{\mathrm{a}}$ \\
\hline & $2^{\text {nd }}$ week & 38.20 & 38.80 & 40.80 & 29.60 & 35.40 & 38.40 \\
\hline & & $\pm 0.37^{\mathrm{b}}$ & $+0.37^{\mathrm{b}}$ & $\pm 0.37^{\mathrm{a}}$ & $\pm 0.24^{\mathrm{d}}$ & $\pm 0.24^{\mathrm{c}}$ & $\pm 0.24^{\mathrm{b}}$ \\
\hline & $4^{\text {th }}$ week & 38.40 & 39.60 & 40.60 & 28.60 & 36.80 & 39.20 \\
\hline & & $\pm 0.24^{\mathrm{c}}$ & $\pm 0.24^{\mathrm{b}}$ & $\pm 0.37^{\mathrm{a}}$ & $\pm 0.24^{\mathrm{e}}$ & $\pm 0.20^{\mathrm{d}}$ & $\pm 0.20^{\mathrm{b}}$ \\
\hline & $6^{\text {th }}$ week & 38.40 & 38.60 & 41.00 & 27.60 & 38.8 & 39.60 \\
\hline & & $\pm 0.24^{\mathrm{b}}$ & $\pm 0.32^{\mathrm{b}}$ & $\pm 0.37^{\mathrm{a}}$ & $\pm 0.24^{\mathrm{c}}$ & $0 \pm 0.20^{\mathrm{b}}$ & $\pm 0.24^{\mathrm{ab}}$ \\
\hline
\end{tabular}

Values are expressed as mean \pm standard error, $n=5$. Means within the same raw carrying different superscripts are significant at $(\mathrm{P} \leq 0.05)$.

\section{Effects on immune status}

The addition of biological antimycotoxin $S$. cerevisiae to the basal diet (Group 3) significantly increase both phagocytic $\%$ and index when compared with control group, while adding of HSCAS to the basal diet (Group 2) evoked non-significant changes in phagocytic $\%$ or index comparing with control (Fig 2 A \& B). There was a significant decrease $(\mathrm{P} \leq 0.05)$ in phagocytic \% and index in descending manner at different experimental periods as indicator for nonspecific immunity in $\mathrm{AFB}_{1}$ group. The addition either of HSCAS or S. cerevisiae to aflatoxicated diet significantly increased $(\mathrm{P} \leq 0.05)$ both phagocytic $\%$ and index compared to $\mathrm{AFB}_{1}$ group all over the experimental periods. $\mathrm{AFB}_{1+} S$. cerevisiae group showed a significant improvement in the phagocytosis when compared to $\mathrm{HSCAS}+\mathrm{AFB}_{1}$ group.

\section{Effects on some biochemical parameters}

Fish fed diet intoxicated with $2.5 \mathrm{ppm}$ $\mathrm{AFB}_{1}$ displayed a marked elevation in ALT, ALP and creatinine (Figs 3 A, B \& C). Those fish also displayed a marked reduction in 
serum total protein, albumin and globulin (Table 2). Addition of HSCAS or S. cerevisiae could ameliorate the alterations of these parameters compared with $\mathrm{AFB}_{1}$ group. Group 6 showed significant decrease in ALT, ALP and creatinine as well as significant increase in serum total protein, albumin and globulin compared to group 5 throughout the experimental period.

\section{Effects on aflatoxin residues}

Exposure of fish to $\mathrm{AFB}_{1}$ intoxicated diet for 42 day resulted in accumulation of aflatoxin residues in $O$. niloticus flesh and liver in ascending manner at different experimental periods till reach high levels (5 $\mathrm{ppb})$ in muscle and (15 ppb) in liver at the end of experiment. Addition of chemical antimycotoxin HSCAS or biological one $S$. cerevisiae to $\mathrm{AFB}_{1}$ treated diet significantly reduced $(\mathrm{P} \leq 0.05)$ aflatoxin residues in both liver and muscle of $O$. niloticus all over the experimental periods. Fish in group 6showed a significant reduction in aflatoxin residues followed fish in group 5 (data not shown).

\section{Discussion}

The mortality rate was increased in fish fed aflatoxin $\mathrm{B}_{1}$ intoxicated diet $(16.7 \%)$ in comparison with control group (0\%). Fish death may be due to the organs dysfunction, anemia and impaired immunity caused by aflatoxicosis as recorded in our study. In similar way, Santacroce et al., [3] stated that the mortality rate increased in fish fed diets contaminated with aflatoxin. Addition either of HSCAS or $S$. cerevisiae to aflatoxin toxicated diet, improved the survival rate $(96 \%)$ when compared with aflatoxicated diet only. This could be attributed to the ability of both antimycotoxins to bind aflatoxin in the gastrointestinal tract decreasing its uptake and bioavailability [25]. Our results were reinforced by Pooramini et al., [26].

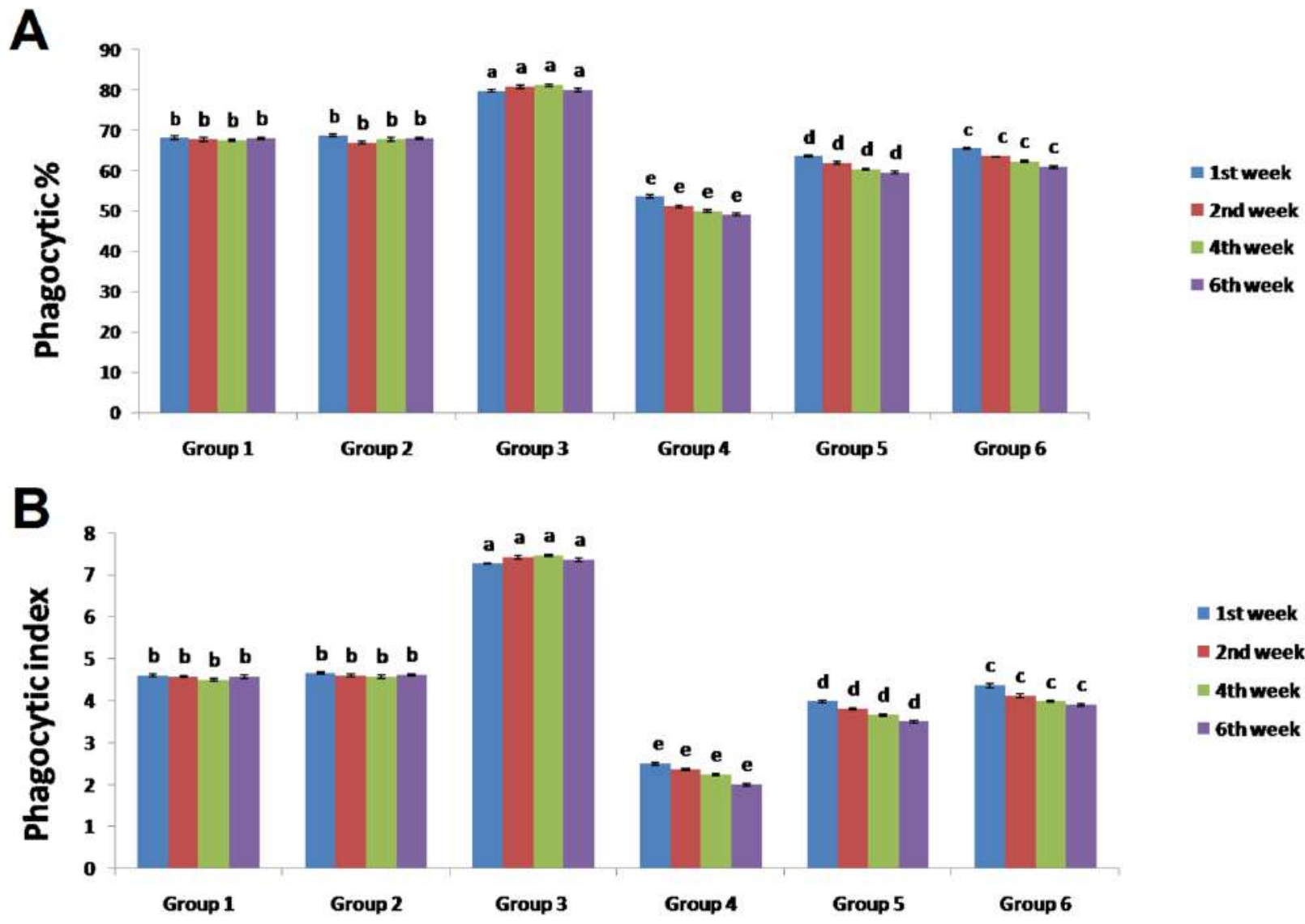

Figure 2: Effect of aflatoxin $B_{1}$ and different antimycotoxins on serum level of phagocytic \% (A), and phagocytic index (B) of $O$. niloticus at different experimental periods. 
$\mathrm{AFB}_{1}$ had adverse impacts on fish hematological parameters, as it significantly decreased RBCs, $\mathrm{PCV} \%, \mathrm{Hb}$ concentration, total WBCs and lymphocytes. Meanwhile, neutrophils significantly increased. Lowering of RBCs, PCV \%, Hb concentration indicated anemia, possibly due to the hemopiotic organs damage mainly anterior kidney [27] or an increase of RBCs destruction in hematopoietic tissues [28]. While, the reduction in leukocytic count may be due to the release of epinephrine during stress, which is capable of causing the spleen contraction and a decrease of leucocytes count, which accordingly results in the weakening of the immune system [29], renders the fish vulnerable to infection. Besides, the release of neutrophils into the blood occurs as a non-specific response to a variety of stress stimuli in mammals and fishes [30]. Our findings were supported by those reported for fish aflatoxicosis in $O$. niloticus $[16,15]$.
Marked elevation in WBCs, RBCs, PCV \% and $\mathrm{Hb}$ in groups 5 and 6 compared with fish in group 4 . This can be explained by the ability of $S$. cerevisiae to degrade mycotoxins and prevent their toxic effects [31] and the ability of HSCAS to bind AF strongly and prevent its absorption across the gastrointestinal tract [32]. Our results were reinforced by Osman et al., [33].

In the present study, $\mathrm{AFB}_{1}$ significantly reduced both phagocytic $\%$ and index, which proved the immunosuppressive effect of aflatoxin. Our results were supported by Sahoo and Mukherjee, [34] who reported that $\mathrm{AFB}_{1}$ cause suppression of neutrophil function, macrophage phagocytic activity, humeral immune response and globulin levels in rohu (Labeo rohita). Furthermore, RodríguezCervantes et al., [35] stated that aflatoxins induced chronic alterations in the immune system of aquatic organisms.

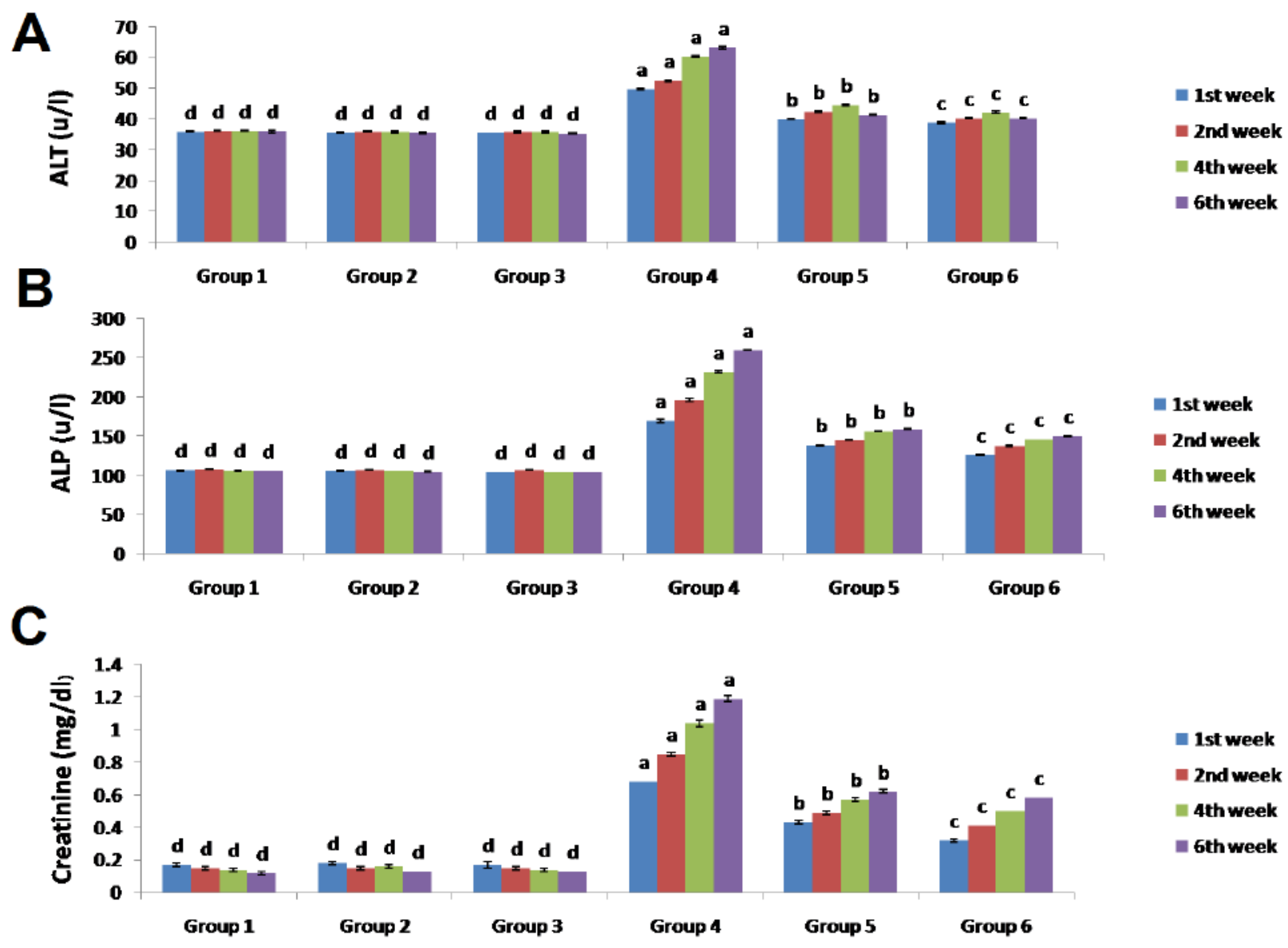

Figure 3: Effect of aflatoxin $B_{1}$ and different antimycotoxins on serum level of ALT (A), ALP (B) and creatinine (C) of $O$. niloticus during experimental periods. 
Adding either HSCAS or $S$. cerevisiae to aflatoxicated diet significantly improved phagocytic \% and index comparing to $\mathrm{AFB}_{1}$ intoxicated group. These results may be attributed to the ability of HSCAS to bind $\mathrm{AFB}_{1}$ in the gastrointestinal tract, reducing bioavailability to the blood stream [36]. Furthermore $S$. cerevisiae contains various immunostimulating compounds [37] beside its ability to capture the mycotoxin molecule changing it into nontoxic substance [10]. Our results are nearly agreed with Wang et al., [38] who reported that $\beta$-glucan enhance phagocytic index in $O$. niloticus fed on aflatoxin treated diet.

Concerning liver and kidney function, fish fed $\mathrm{AFB}_{1}$ treated diet showed a significant increase in ALT, ALP and creatinine as well as significant decrease in total protein, albumin and globulin indicating the stressful effects of $\mathrm{AFB}_{1}$ on the hepatic and renal tissues and impairment of their function. The reduction in total protein and albumin could be attributed partly to the damaging effects of $\mathrm{AFB}_{1}$ on hepatic cells [34], which was detected in this study, as evidenced by the increase in serum ALT and ALP activities, whereas the reduced globulin levels in $\mathrm{AFB}_{1^{-}}$ treated fish may be due the result of lymphocytolysis [39]. Our results were strengthened by those reported for aflatoxicosis in O. niloticus [40].

Supplementation of $\mathrm{AFB}_{1}$ toxicated diet either with HSCAS or $S$. cerevisiae could alleviate the alterations of biochemical parameters compared to $\mathrm{AFB}_{1}$ group. This could explain by the ability of $S$. cerevisiae and HSCAS to bind with mycotoxins and limit their bioavailability in the digestive tract and protect animals against its adverse effects. Our results were reinforced by those previously recorded $[41,15,42]$.

Table 2: Effect of aflatoxin $B_{1}$ and different antimycotoxins on serum total protein, albumin and globulin of $O$. niloticus during experimental periods

\begin{tabular}{|c|c|c|c|c|c|c|c|}
\hline Groups & Period & G1 & G2 & G3 & G4 & G5 & G6 \\
\hline \multirow{8}{*}{$\begin{array}{l}\text { Total protein } \\
\text { (g/dl) }\end{array}$} & $1^{\text {st }}$ week & $7.03 \pm 0.09^{\mathrm{a}}$ & $7.02 \pm$ & $7.07 \pm$ & $4.94 \pm$ & $5.99 \pm$ & $6.21 \pm$ \\
\hline & & & $0.07^{\mathrm{a}}$ & $0.07^{\mathrm{a}}$ & $0.07^{\mathrm{d}}$ & $0.03^{\mathrm{c}}$ & $0.06^{\mathrm{b}}$ \\
\hline & $2^{\text {nd }}$ week & $7.19 \pm 0.12^{\mathrm{a}}$ & $7.07 \pm$ & $7.13 \pm$ & $4.19 \pm$ & $5.36 \pm$ & $5.92 \pm$ \\
\hline & & & $0.11^{\mathrm{a}}$ & $0.10^{\mathrm{a}}$ & $0.04^{\mathrm{d}}$ & $0.05^{\mathrm{c}}$ & $0.03^{b}$ \\
\hline & $4^{\text {th }}$ week & $7.03 \pm$ & $7.04 \pm$ & $7.08 \pm$ & $3.45 \pm$ & $5.15 \pm$ & $5.52 \pm$ \\
\hline & & $0.07^{\mathrm{a}}$ & $0.06^{\mathrm{a}}$ & $0.05^{\mathrm{a}}$ & $\_.0 .07^{\mathrm{d}}$ & $0.05^{\mathrm{c}}$ & $0.04^{b}$ \\
\hline & $6^{\text {th }}$ week & $6.94 \pm 0.07^{\mathrm{a}}$ & $6.94 \pm$ & $7.01 \pm$ & $2.87 \pm$ & $5.01 \pm$ & $5.25 \pm$ \\
\hline & & & $0.06^{\mathrm{a}}$ & $0.05^{\mathrm{a}}$ & $0.09^{\mathrm{d}}$ & $0.03^{c}$ & $0.02^{\mathrm{b}}$ \\
\hline \multirow{8}{*}{$\begin{array}{l}\text { Albumin } \\
\text { (g/dl) }\end{array}$} & $1^{\text {st }}$ week & $4.20 \pm 0.02^{\mathrm{a}}$ & $4.20 \pm$ & $4.22 \pm$ & $3.78 \pm 0.02^{\mathrm{c}}$ & $3.99 \pm$ & $4.05 \pm$ \\
\hline & & & $0.02^{\mathrm{a}}$ & $0.02^{\mathrm{a}}$ & & $0.04^{\mathrm{b}}$ & $0.06^{\mathrm{b}}$ \\
\hline & $2^{\text {nd }}$ week & $4.21 \pm 0.02^{\mathrm{a}}$ & $4.21 \pm$ & $4.21 \pm$ & $3.20 \pm$ & $3.76 \pm$ & $3.93 \pm$ \\
\hline & & & $0.03^{\mathrm{a}}$ & $0.03^{\mathrm{a}}$ & $0.02^{\mathrm{d}}$ & $0.03^{\mathrm{c}}$ & $0.02^{\mathrm{b}}$ \\
\hline & $4^{\text {th }}$ week & $4.16 \pm 0.01^{\mathrm{a}}$ & $4.18 \pm$ & $4.19 \pm$ & $2.99 \pm$ & $3.38 \pm$ & $3.47 \pm$ \\
\hline & & & $0.01^{\mathrm{a}}$ & $0.02^{\mathrm{a}}$ & $0.02^{\mathrm{d}}$ & $0.01^{\mathrm{c}}$ & $0.01^{\mathrm{b}}$ \\
\hline & $6^{\text {th }}$ week & $4.16 \pm$ & $4.17 \pm$ & $4.19 \pm$ & $2.42 \pm$ & $3.29 \pm$ & $3.36 \pm$ \\
\hline & & $0.01^{\mathrm{a}}$ & $0.01^{\mathrm{a}}$ & $0.02^{\mathrm{a}}$ & $0.02^{\mathrm{d}}$ & $0.01^{\mathrm{c}}$ & $0.01^{\mathrm{b}}$ \\
\hline \multirow{8}{*}{$\begin{array}{l}\text { Globulin } \\
\text { (g/dl) }\end{array}$} & $1^{\text {st }}$ week & $2.83 \pm$ & $2.82 \pm$ & $2.85 \pm$ & $1.40 \pm$ & $1.92 \pm$ & $2.13 \pm$ \\
\hline & & $0.07^{\mathrm{a}}$ & $0.05^{\mathrm{a}}$ & $0.05^{\mathrm{a}}$ & $0.01^{\mathrm{d}}$ & $0.02^{\mathrm{c}}$ & $0.02^{\mathrm{b}}$ \\
\hline & $2^{\text {nd }}$ week & $2.98 \pm 0.10^{\mathrm{a}}$ & $2.86 \pm$ & $2.92 \pm$ & $1.08 \pm$ & $1.62 \pm$ & $1.98 \pm$ \\
\hline & & & $0.08^{\mathrm{a}}$ & $0.08^{\mathrm{a}}$ & $0.02^{\mathrm{d}}$ & $0.02^{\mathrm{c}}$ & $0.01^{\mathrm{b}}$ \\
\hline & $4^{\text {th }}$ week & $2.96 \pm 0.03^{\mathrm{a}}$ & $2.86 \pm$ & $2.89 \pm$ & $0.57 \pm$ & $1.77 \pm$ & $2.05 \pm$ \\
\hline & & & $0.05^{\mathrm{b}}$ & $0.03^{\mathrm{ab}}$ & $0.01^{\mathrm{e}}$ & $0.03^{\mathrm{d}}$ & $0.03^{\mathrm{c}}$ \\
\hline & $6^{\text {th }}$ week & $2.78 \pm 0.06^{\mathrm{a}}$ & $2.77 \pm$ & $2.82 \pm$ & $0.44 \pm$ & $1.73 \pm$ & $1.89 \pm$ \\
\hline & & & $0.06^{\mathrm{a}}$ & $0.04^{\mathrm{a}}$ & $0.07^{\mathrm{d}}$ & $0.02^{\mathrm{c}}$ & $0.02^{\mathrm{b}}$ \\
\hline
\end{tabular}

Values are expressed as mean \pm standard error, $n=5$. Means within the same raw carrying different superscripts are significant at $(\mathrm{P} \leq 0.05)$. 
Maintainable mycotoxin residues in fish are a food safety problem [43]. In the current work, exposure to $2.5 \mathrm{mg} \mathrm{AFB} / 1 \mathrm{~kg}$ diet for 42 day resulted in accumulation of aflatoxin residues in Nile tilapia flesh and liver in ascending increase manner at different experimental periods till reach high levels (5 $\mathrm{ppb})$ in muscle and (15 ppb) in liver at the end of experiment. Most of $\mathrm{AFB}_{1}$ residues were recorded mainly in the liver. These findings indicate that liver has an essential role in $\mathrm{AFB}_{1}$ metabolism, toxic metabolites activation or detoxification [44,45]. Our results strengthened by Deng et al., [46] who detected $\mathrm{AFB}_{1}$ residues in Nile tilapia liver when received smaller doses of toxin (less than $2 \mathrm{mg} / \mathrm{kg}$ ). Moreover, Rajeev Raghavan et al., [47] concluded that residual $\mathrm{AFB}_{1}$ was detected at high levels (5 ppb) in fish musculature after prolonged feeding of sea bass with low levels of $\mathrm{AFB}_{1}$.

Supplementation of $\mathrm{AFB}_{1}$ toxicated diet either with HSCAS or $S$. cerevisiae reduced residues of aflatoxin significantly in liver and muscle of $O$. niloticus indicating the protection of fish liver and musculature against $\mathrm{AFB}_{1}$ residues by HSCAS and $S$. cerevisiae through their ability to bind aflatoxin and formation of adduct which is not affected by the gastrointestinal tract enzymes consequently reduce the toxin bioavailability.

\section{Conclusion}

From the previously mentioned outcomes, it could be concluded that the supplementation of $\mathrm{AFB}_{1}$ intoxicated diet either with $0.25 \% \mathrm{~S}$. cerevisiae or $0.5 \%$ HSCAS succeed in mitigation of the drastic effects of aflatoxin on survival rate, hematology, phagocytosis and biochemical parameters as well as its residues in $O$. niloticus. Furthermore, $S$. cerevisiae appear to be more effective in protection of fish from aflatoxicosis than HSCAS.

\section{Conflict of interest}

The authors declare that they have no conflict of interest.

\section{Acknowledgments}

Authors would like to acknowledge Prof. Dr. Mahmoud Arafa Mohamed, Chief Researcher of Biochemistry, Toxicology and
Feed Deficiency Department, Animal Health Research Institute, El-Dokki, for his help in $\mathrm{AFB}_{1}$ preparation.

\section{References}

[1] Mehrim, I.A., Refaey, M.M., Elmeleigy, K.M., 2016. Glutathione-Enhancer ${ }^{\mathrm{TM}}$ Against Foodborne Aflatoxicosis of Oreochromis niloticus (Linnaeus, 1758). J Fish Aquat Sci, 11: 131-146.

[2] McKean, C., Tang, L., Tang, M., Billam, M., Wang, Z., Theodorakis, C.W., Kendall, R.J., Wang, J.S., 2006. Comparative acute and combinative toxicity of aflatoxin B1 and fumonisin B1 in animals and human cells. Food and chemical toxicology : an international journal published for the British Industrial Biological Research Association 44, 868876.

[3] Santacroce, M.P., Conversano, M.C., Casalino, E., Lai, O., Zizzadoro, C., Centoducati, G., Crescenzo, G., 2008. Aflatoxins in aquatic species: metabolism, toxicity and perspectives. Rev Fish Biol Fish 18, 99-130.

[4] Han, X.-Y., Huang, Q.-C., Li, W.-F., Jiang, J.-F., Xu, Z.-R., 2008. Changes in growth performance, digestive enzyme activities and nutrient digestibility of cherry valley ducks in response to aflatoxin B1 levels. Livest Sci, 119: 216-220.

[5] Santos, G.A., Rodrigues , I., Naehrer, K., Encarnação, P., 2010. Mycotoxins in aquaculture: Occurrence in feed components and impact on animal performance. Aquacult Eur, 35: 6-10.

[6] Kabak, B., Dobson, A.D., Var, I., 2006. Strategies to prevent mycotoxin contamination of food and animal feed: a review. Critical Rev Food Sci Nutr 46, 593-619.

[7] Phillips, T.D., Kubena, L.F., Harvey, R.B., Taylor, D.R., Heidelbaugh, N.D., 1988. Hydrated sodium calcium aluminosilicate: a high affinity sorbent for aflatoxin. Poult Sci 67, 243-247.

[8] Parlat, S.S., Ozcan, M., Oguz, H., 2001. Biological suppression of aflatoxicosis in 
Japanese quail (Coturnix coturnix japonica) by dietary addition of yeast (Saccharomyces cerevisiae). Res Vet Sci, 71: 207-211.

[9] Stanley, V.G., Ojo, R., Woldesenbet, S., Hutchinson, D.H., Kubena, L.F., 1993. The use of Saccharomyces cerevisiae to suppress the effects of aflatoxicosis in broiler chicks. Poult Sci, 72: 1867-1872.

[10] Yiannikouris, A., Francois, J., Poughon, L., Dussap, C.G., Bertin, G., Jeminet, G., Jouany, J.P., 2004. Adsorption of Zearalenone by beta-D-glucans in the Saccharomyces cerevisiae cell wall. J Food Protect, 67: 1195-1200.

[11] Diaz, D.E., Hagler, W.M., Jr., Hopkins, B.A., Whitlow, L.W., 2002. Aflatoxin binders I: in vitro binding assay for aflatoxin B1 by several potential sequestering agents. Mycopathol, 156: 223-226.

[12] Freimund, S., Sauter, M., Rys, P., 2003. Efficient adsorption of the mycotoxins zearalenone and T-2 toxin on a modified yeast glucan. J Environ Sci Health B, 38: 243-255.

[13] Shotwell, O.L., Hesseltine, C.W., Stubblefield, R.D., Sorenson, W.G., 1966. Production of aflatoxin on rice. Appl Microbiol, 14: 425-428.

[14] Mehrim, A.I., Abdelhamid, A.M., AbouShousha, A., M.F., S., El-Sharawy, M.A., 2006. Nutritious attempts to detoxify aflatoxic diets of tilapia fish: clinical, biochemical and histological parameters. J Arab Aqua Soci, 1: 69-90.

[15] Selim, K.M., El-hofy, H., Khalil, R.H., 2014. The efficacy of three mycotoxin adsorbents to alleviate aflatoxin B1induced toxicity in Oreochromis niloticus. Aqua Int 22, 523-540.

[16] Anh Tuan, N., Grizzle, J.M., Lovell, R.T., Manning, B.B., Rottinghaus, G.E., 2002. Growth and hepatic lesions of Nile tilapia (Oreochromis niloticus) fed diets containing aflatoxin B1. Aqua, 212: 311319.
[17] Lee, L.F., Bacon, L.D., 1983. Ontogeny and line differences in the mitogenic response of chicken lymphocytes. Poult Sci, 62: 579-584.

[18]Thompson, R.A., 1977. Techniques in clinical immunology. Blackwell Scientific Publications, Osney Mead, Oxford OX2 OEL.

[19]Reitman, S., Frankel, S., 1957. A colorimetric method for the determination of serum glutamic oxalacetic and glutamic pyruvic transaminases. Am J Clin Pathol, 28: 56-63.

[20]Tietz, N.W., Burtis, C.A., Duncan, P., Ervin, K., Petitclerc, C.J., Rinker, A.D., Shuey, D., Zygowicz, E.R., 1983. A reference method for measurement of alkaline phosphatase activity in human serum. Clin Chem, 29: 751-761.

[21]Lowry, O.H., Rosebrough, N.J., Farr, A.L., Randall, R.J., 1951. Protein measurement with the Folin phenol reagent. J Biol Chem, 193: 265-275.

[22]Doumas, B.T., Watson, W.A., Biggs, H.G., 1971. Albumin standards and the measurement of serum albumin with bromcresol green. Clin Chim acta, 31: 8796.

[23] Larsen, K., 1972. Creatinine assay by a reaction-kinetic principle. Clin Chim acta, 41: 209-217.

[24]AOAC, 2000. Official methods of analysis, 15th Ed. . Association of Official Analysis of Chemist,Washington.

[25] Galvano, F., Piva, A., Ritieni, A., Galvano, G., 2001. Dietary strategies to counteract the effects of mycotoxins: a review. J Food Protect, 64: 120-131.

[26]Pooramini, M., Kamali, A., Hajimoradloo, A., Alizadeh, M., Ghorbani, R., 2009. Effect of using yeast (Saccharomyces cerevisiae) as probiotic on growth parameters, survival and carcass quality in rainbow trout Oncorhynchus mykiss fry. Int Aquat Res, 1: 39-44.

[27] Pepeljnjak, S., Petrinec, Z., Kovacic, S., Segvic, M., 2003. Screening toxicity study in young carp (Cyprinus carpio L.) on 
feed amended with fumonisin B1. Mycopathol, 156: 139-145.

[28]Jenkins, F., Smith, J., Rajanna, B., Shameem, U., Umadevi, K., Sandhya, V., Madhavi, R., 2003. Effect of sub-lethal concentrations of endosulfan on hematological and serum biochemical parameters in the carp Cyprinus carpio. Bull Environ Contam Toxicol, 70: 993997.

[29] Witeska, M., 2003. The Effects of Metals $(\mathrm{Pb}, \mathrm{Cu}, \mathrm{Cd}$, and $\mathrm{Zn})$ on Hematological Parameters and Blood Cell Morphology of Common Carp. Rozprawa naukowa nr 72, Wydawnictwo Akademii Podlaskiej Siedlce, 113 pp, [In Polish].

[30] Singh, D., Nath, K., Trivedi, S.P., Sharma, Y.K., 2008. Impact of copper on haematological profile of freshwater fish, Channa punctatus. J Environ Biol, 29: 253-257.

[31] Yiannikouris, A., Andre, G., Poughon, L., Francois, J., Dussap, C.G., Jeminet, G., Bertin, G., Jouany, J.P., 2006. Chemical and conformational study of the interactions involved in mycotoxin complexation with beta-D-glucans. Biomacromol, 7: 1147-1155.

[32]Oguz, H., 2012. Detoxification of aflatoxin in poultry feed: a review from experimental trials Lohmann Information $47,45-56$.

[33] Osman, H.A.M., Ibrahim, T.B., Soliman, W.E., Monier, M.M., 2010 Influence of dietary commercial beaker's yeast, Saccharomyces cerevisae on growth performance, survival and immunostimulation of Oreochromis niloticus challenged with Aeromonas hydrophila. Nat Sci, 8: 96-103.

[34] Sahoo, P.K., Mukherjee, S.C., 2001. Immunosuppressive effects of aflatoxin B1 in Indian major carp (Labeo rohita). Com Immunol Microbiol Infect Dis, 24: 143-149.

[35]Rodríguez-Cervantes, C., Girón-Pérez, M., Robledo-Marenco, M., Marín, S., Velázquez-Fernández, J., Medina-Díaz, I., Rojas-García, A., Ramos, A., 2010.
Aflatoxin B1 and its toxic effects on immune response of teleost fishes: a review. World Mycot J, 3: 193-199.

[36]Phillips, T.D., Clement, B.A., Kubena, L.F., Harvey, R.B., 1990. Detection and detoxification of aflatoxins: prevention of aflatoxicosis and aflatoxin residues with hydrated sodium calcium aluminosilicate. Vet Human Toxicol, 32: 15-19.

[37]Li, P., Gatlin III, D.M., 2004. Dietary brewers yeast and the prebiotic Grobiotic $^{\mathrm{TM}} \mathrm{AE}$ influence growth performance, immune responses and resistance of hybrid striped bass (Morone chrysops $\times$ M. saxatilis) to Streptococcus iniae infection. Aquacult, 231: 445-456.

[38] Wang, W.S., Hung, S.W., Lin, Y.H., Tu, C.Y., Wong, M.L., Chiou, S.H., Shieh, M.T., 2007. The effects of five different glycans on innate immune responses by phagocytes of hybrid tilapia and Japanese eels Anguilla japonica. J Aquat Anim Health, 19: 49-59.

[39] Sahoo, P.K., Mukherjee, S.C., Jain, A.K., Mukherjee , A., 1998. Light and ultrastructural changes in opisthonephros of rohu, Labeo rohita during acute and subchronic aflatoxin B1 toxicity (abstract). , , In: In: International conference on fisheries food security beyond the year 2000, Chiang Mai, Thailand, p. p 212

[40]El-Barbary, M.I., 2016. Detoxification and antioxidant effects of garlic and curcumin in Oreochromis niloticus injected with aflatoxin B1 with reference to gene expression of glutathione peroxidase (GPx) by RT-PCR. Fish Physiol Biochem, 42: 617-629.

[41]Phillips, T.D., Afriyie-Gyawu, E., Williams, J., Huebner, H., Ankrah, N.A., Ofori-Adjei, D., Jolly, P., Johnson, N., Taylor, J., Marroquin-Cardona, A., Xu, L., Tang, L., Wang, J.S., 2008. Reducing human exposure to aflatoxin through the use of clay: a review. Food Addit Contam Part A Chem Anal Control Expo Risk Assess, 25: 134-145. 
[42] Wang, P., Afriyie-Gyawu, E., Tang, Y., Johnson, N.M., Xu, L., Tang, L., Huebner, H.J., Ankrah, N.A., Ofori-Adjei, D., Ellis, W., Jolly, P.E., Williams, J.H., Wang, J.S., Phillips, T.D., 2008. NovaSil clay intervention in Ghanaians at high risk for aflatoxicosis: II. Reduction in biomarkers of aflatoxin exposure in blood and urine. Food Addit Contam Part A Chem Anal Control Expo Risk Assess, 25: 622-634.

[43]El-Banna, R., Teleb, H., Hadi, M., Fakhry, F., 1992. Performance and tissue residue of tilapias fed dietary aflatoxin. Vet Med $\mathrm{J}$.

[44]Guengerich, F.P., Johnson, W.W., Shimada, T., Ueng, Y.F., Yamazaki, H., Langouet, S., 1998. Activation and detoxication of aflatoxin B1. Mut Res, 402: 121-128.
[45] Takahashi, N., Stresser, D.M., Williams, D.E., Bailey, G.S., 1995. Induction of hepatic CYP1A by indole-3-carbinol in protection against aflatoxin B1 hepatocarcinogenesis in rainbow trout. Food Chem Toxicol, 33: 841-850.

[46]Deng, S.-X., Tian, L.-X., Liu, F.-J., Jin, S.-J., Liang, G.-Y., Yang, H.-J., Du, Z.Y., Liu, Y.-J., 2010. Toxic effects and residue of aflatoxin $\mathrm{B} 1$ in tilapia (Oreochromis niloticus $\times$ O. aureus) during long-term dietary exposure. Aquacult, 307: 233-240.

[47] Rajeev Raghavan, P., Zhu, X., Lei, W., Han, D., Yang, Y., Xie, S., 2011. Low levels of Aflatoxin B1 could cause mortalities in juvenile hybrid sturgeon, Acipenser ruthenus $\lambda \times \mathrm{A}$. baerior. Aquacult Nutr, 17: e39-e47.

\section{الملخص العربى}

التأثير التحفيزي المقارن لكالسيوم ألومينوسيليكات الصوديوم وسكروميسز سيريفيسياي (خميرة بروير) ضد التأثير السام للأفلاتوكسين B1 في أسماتك البلطي النيلي

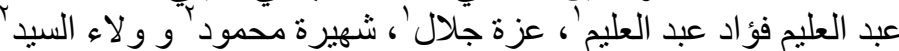

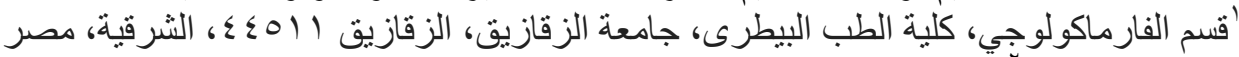

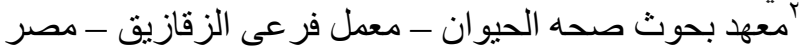

تعتبر الثروة السمكيه من أهم مصادر البروتين الحيوانى. ووجود السموم الفطريه فى الأعلاف من أهم المشكلات التى تواجها

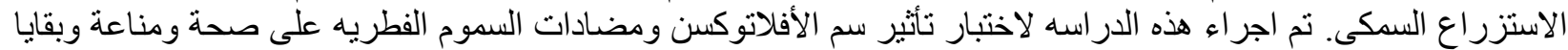

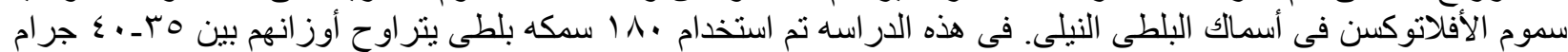

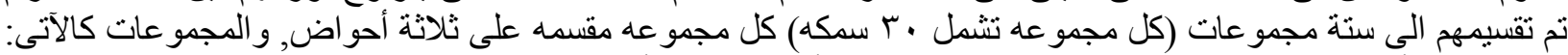

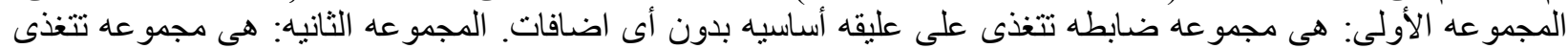

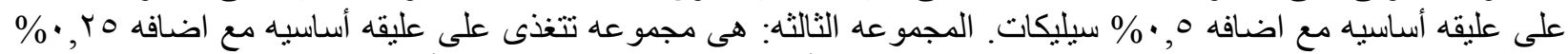

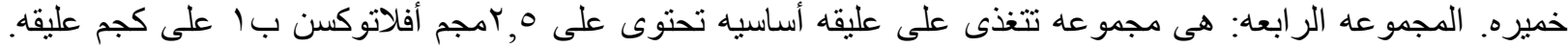

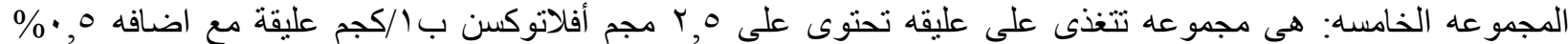

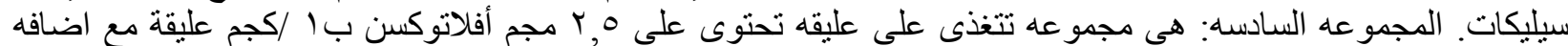

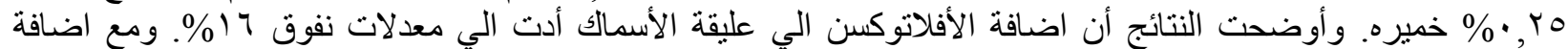

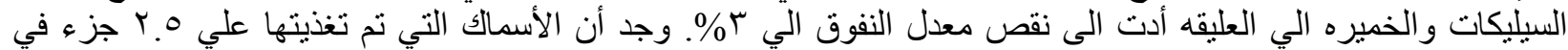

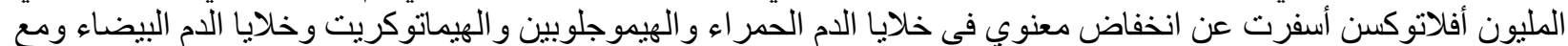

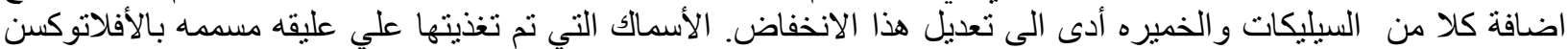

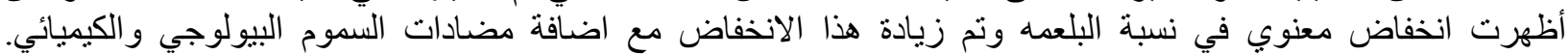

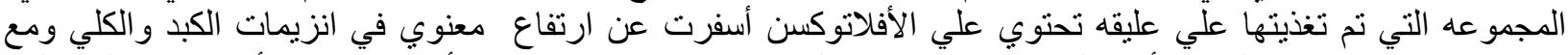

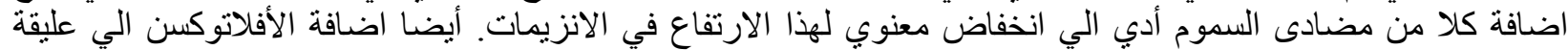

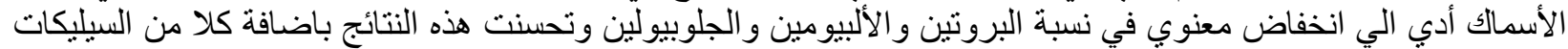

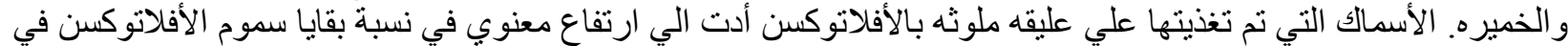

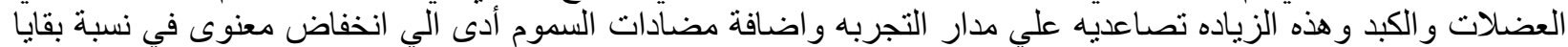

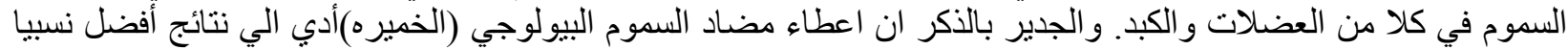

